\title{
Spontaneous pneumothorax in children - management, results, and review of the literature
}

\author{
Ewa Matuszczak, Wojciech Dębek, Adam Hermanowicz, Marzena Tylicka \\ Paediatric Surgery Clinic, Medical University of Bialystok, Poland
}

Kardiochirurgia i Torakochirurgia Polska 2015; 12 (4): 322-327

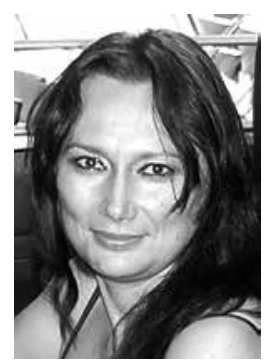

\begin{abstract}
Introduction: Primary spontaneous pneumothorax (PSP) occurs at a frequency of 7.4-18 cases per 100000 population per year. The PSP typically occurs in young adults and is uncommon in children. The aim of this study was to review our institutional experience with PSP in children.

Material and methods: Twenty-two paediatric patients with confirmed PSP, treated from 2004 to 2014 at the Paediatric Surgery Clinic. There were 18 boys and 4 girls. The mean age was 16 years, 6 months \pm 1 month (range 14-17). The mean body mass index (BMI) was 20.1 (ranging from 17 to 24).

Results: The recurrence rate of PSP was $48 \%$. The mean interval of the recurrence was 5 months \pm 1 month (range from 3 weeks to 2 years). Recurrent pneumothorax was evacuated by thoracostomy with success in four patients. The first videoassisted thoracoscopic surgery (VATS) procedure had a failure rate of $50 \%$. After second VATS procedure, we did not observe recurrent PSP in two patients. One patient with recurrent PSP, after two VATS procedures, was treated with success, with an open mini axillary thoracotomy. The mean follow-up period was 4 years 3 months \pm 1 month (range 6 months -10 years). We have not noted any intraoperative complications.

Conclusions: Although our study is limited by the small number of patients, we conclude that most patients resolve their spontaneous pneumothorax and air leak with tube thoracostomy alone. For those patients in whom chest tube drainage is not effective, and for those with recurrent PSP, early VATS and bullectomy combined with pleural abrasion is the most efficient intervention.
\end{abstract}

Key words: spontaneous pneumothorax, children, VATS, thoracostomy, pleurodesis.

\section{Streszczenie}

Wstęp: Samoistna odma opłucnowa występuje przeważnie $u$ astenicznych osób, w wieku ok. 18-40 lat. Znacznie częściej chorują mężczyźni niż kobiety. Powstaje zazwyczaj z przyczyn nieznanych. Celem pracy było przedstawienie trudności w leczeniu chirurgicznym samoistnej odmy opłucnowej u dzieci.

Materiał i metody: Dokonano analizy dokumentacji medycznej pacjentów z samoistną odmą opłucnową leczonych w Klinice Chirurgii Dziecięcej Uniwersytetu Medycznego w Białymstoku. W latach 2004-2014 hospitalizowano 22 dzieci z powodu samoistnej odmy opłucnowej - 18 chłopców i 4 dziewczynki, w wieku od 14 do 17 lat (średnio 16,6 miesiąca).

Wyniki: W 11 przypadkach (52\%) w leczeniu jednostronnej odmy opłucnowej zastosowano jednorazowy drenaż jamy opłucnowej, z dobrym skutkiem. W pozostałych 11 przypadkach wystąpił nawrót odmy, w czasie od 3 tygodni do 2 lat. $\mathrm{U}$ pacjentów z odmą nawrotową wykonano drenaż jamy opłucnowej oraz tomografię komputerową (TK) klatki piersiowej. Sześciu pacjentów z tej grupy, na podstawie obrazu TK, w którym stwierdzono obecność pęcherzy rozedmowych, zakwalifikowano do torakoskopii (video-assisted thoracoscopic surgery - VATS). W trakcie VATS wykonano zamknięcie przetok oskrzelowo-opłucnowych w obrębie pękniętych pęcherzy rozedmowych za pomocą pętli endoloop. Z powodu utrzymującego się przecieku powietrza w 3 przypadkach wykonano ponownie VATS. U chłopca, u którego nie stwierdzono efektu terapeutycznego po VATS, wykonano minitorakotomię z dostępu pod pachą - za pomocą staplera usunięto szczyt płuca oraz wykonano pleurodezę, z dobrym skutkiem.

Wnioski: Poznanie czynników ryzyka powstania nawrotowej samoistnej odmy opłucnowej pozwala na kwalifikowanie chorych do odpowiednich, małoinwazyjnych procedur leczniczych - VATS. W przypadku niepowodzenia VATS, minitorakotomia pachowa zapewnia powodzenie leczenia, zaoszczędzając choremu bólu pooperacyjnego i zapewniając dobry efekt kosmetyczny.

Słowa kluczowe: odma opłucnowa samoistna, dzieci, VATS, torakoskopia.

Address for correspondence: Dr Ewa Matuszczak, Paediatric Surgery Clinic, Medical University of Bialystok, 17 Waszyngtona St., 15-274 Białystok, Poland, phone: +48 608430 844, e-mail: ewamat@tlen.pl 


\section{Introduction}

A primary spontaneous pneumothorax (PSP) is defined as a spontaneously occurring pneumothorax in a person without clinically apparent underlying lung disease or trauma. The PSP occurs at a frequency of 7.4-18 cases per 100,000 population per year in men and $1.2-6$ cases per 100,000 population per year in women [1]. The PSP typically occurs in young adults (peak age incidence $20-30$ years) and is uncommon in the paediatric population $[2,3]$. Therefore the research on PSP has focused on management strategies in adults, and paediatric population data are lacking [4]. The management of PSP varies and depends on the experience and the speciality of the physician-in-charge [1].

The aim of this study was to review paediatric spontaneous pneumothorax and describe diagnostic and therapeutic approaches and to review our institutional experience with spontaneous pneumothorax.

\section{Material and methods}

The patients in this study consisted of 22 consecutive paediatric patients with confirmed PSP, who were treated from 2004 to 2014 at the Paediatric Surgery Clinic and were identified from an administrative database. The data were collected by retrospective medical record review.

Patients with PSP or recurrent PSP were included. We excluded patients with secondary pneumothorax due to external or surgical trauma, underlying lung disease (asthma, malignancy, infection, connective tissue disease, or congenital lung disease).

Demographic and clinical data were collected, including preoperative factors (age, height, weight), duration of hospital stay from the time of presentation to the ED to discharge, length/duration/type of preoperative management, type of procedure, recurrence of pneumothorax, failure rate of the procedure, length of postoperative air leak, narcotic requirement, and complications.

The patients were predominantly male - there were 18 boys and 4 girls (boys to girls ratio $4: 1$ ). The mean age of the patients was 16 years, 6 months \pm month (range 14-17). The mean body mass index was 20.1 (ranging from 17 to 24).

In all patients, the diagnosis of PSP was confirmed by chest radiographs.

In 11 patients (52\%), chest tubes inserted on diagnosis of the pneumothorax were removed 48 hours after placement and resulted in resolution of the pneumothorax without need for additional intervention. One patient with persistent air leak after chest tube placement for more than seven days have had computed tomography (CT) of the chest, and after confirming of the existence of apical blebs was treated with video-assisted thoracoscopic surgery (VATS) procedure with success. Another 10 patients were hospitalised because of recurrence of PSP, from three weeks to two years after the first episode of PSP (mean 5 months \pm 1 month). All of those patients were treated with thoracostomy and had $C T$ of the chest performed. In five patients, CT of the chest revealed the apical blebs, and those patients were treated with VATS, and blebs resection was performed using Endoloops.
Prolonged postoperative air leak (over seven days) was observed in three patients (50\%); those patients required reoperation during the same hospitalisation. One of those patients had resection of the apex of the lung with endoGIA stapler. Another patient with recurrent PSP, after two VATS procedures that failed to visualise apical blebs, was treated with success using an open mini axillary thoracotomy and resection of apical blebs with endo-GIA stapler.

All chest tubes were inserted using strict sterile technique. The tube was placed over a needle after instilling local anaesthetic in the fifth intercostal space at the midaxillary line. Chest tubes were secured to the skin with suture, and a sterile dressing was applied after attaching the chest tube to a underwater seal collection system set at $10 \mathrm{~cm}$ $\mathrm{H}_{2} \mathrm{O}$ suction. Chest tubes were removed if there was no pneumothorax and no air leak. A chest X-ray was repeated 4-6 hours after removal to evaluate for recurrent pneumothorax. Three of the patients with pneumothorax required longer than 48 hours before chest tube removal but did not require additional intervention. Another two patients were operated on because of persistent air leak after chest tube placement for over seven days.

Before the surgical intervention, a chest $\mathrm{CT}$ was routinely performed for patients with recurrent PSP to localise the bullae and blebs, which identified apical blebs in 6 out of 11 patients (54.5\%).

Indications for operation - video-assisted thoracoscopic surgery (VATS) - were: persistent air leak after chest tube placement for more than seven days in one patient, recurrent ipsilateral pneumothorax in four patients, and occurrence of a contralateral pneumothorax in one patient with apical blebs confirmed in $\mathrm{CT}$ of the chest.

All operations were performed under general anaesthesia. Patients were placed in a lateral decubitus position. Valved trocars were used to allow $\mathrm{CO}_{2}$ insufflation to assist with lung compression and to allow visualisation of the entire visceral pleura. Insufflation pressure of $4 \mathrm{mmHg}$ was used. Video-assisted thoracoscopic surgery procedures were performed under a 5-mm thoracoscopic view using a standard three-port approach. A 5-mm trocar was introduced through an intercostal space in the midaxillary line for insertion of a $30^{\circ}$ telescope. If the patient already had a chest tube, this was removed and the chest tube tract was used for insertion of a second $5-\mathrm{mm}$ trocar for insertion of operating instruments. A third trocar was inserted in the anterior axillary line, $5 \mathrm{~mm}$ or $12 \mathrm{~mm}$ trocar, for insertion of an Endoloop or an endo-GIA stapler if blebectomy was to be performed. In the absence of evident bullae, $250 \mathrm{ml}$ of saline solution was instilled into the pleural cavity and the lung was ventilated to identify the air leak. At the time of the initial VATS procedure, apical blebs were identified in four out of five patients. If blebs were visualised, bleb resection was performed using Endoloops or an endoscopic stapling device (Figs. 2-4). After lung tissue resection no reinforcing materials or tissue sealants were used. The lung was inspected for bleeding and, after pulmonary reinsufflation, checked for air leaks. 
Mechanical pleurodesis was achieved using a cautery scratch. At the end of the procedure, two chest tubes were inserted under direct vision through the trocar sites. All resected blebs were examined histologically and confirmed. The chest tubes were typically removed when the air leak ceased and postoperative chest radiographs showed no residual pneumothorax.

On average, postoperative pain medications, which included Perfalgan, Dolargan, or morphine, were given intravenously or intramuscularly for 1-2 days, after which the patients were given oral analgesics. The mean hospital length of stay was 6.5 days.

\section{Results}

Nine of the initial pneumothoraxes were left-sided and 13 were right-sided. The overall recurrence rate of PSP was $48 \%$. The mean interval between the initial hospitalisation and recurrence was 5 months \pm 1 month (range from 3 weeks to 2 years). Recurrent pneumothorax was evacuated by closed thoracostomy with success in four patients (40\%). The first VATS procedure had an overall major failure rate of $50 \%$. After a second VATS procedure in three patients, we did not observe recurrent PSP in two of these patients. One patient with recurrent PSP, after two VATS procedures failed to visualise apical blebs, was treated successfully with an open mini axillary thoracotomy and resection of apical blebs with endo-GIA stapler (Fig. 1 and 4). The mean follow-up period was 4 years 3 months \pm 1 month (range 6 months - 10 years).

We did not note any intraoperative complications. The postoperative course was uneventful. There were no postoperative deaths, and none of the patients required monitoring in the intensive care unit.

\section{Statistics}

Data are presented as the mean \pm standard deviation or frequencies and percentages, as appropriate. Comparisons were made using Mann-Whitney $U$ test and $\chi^{2}$, as appropriate, and statistical significance was considered when

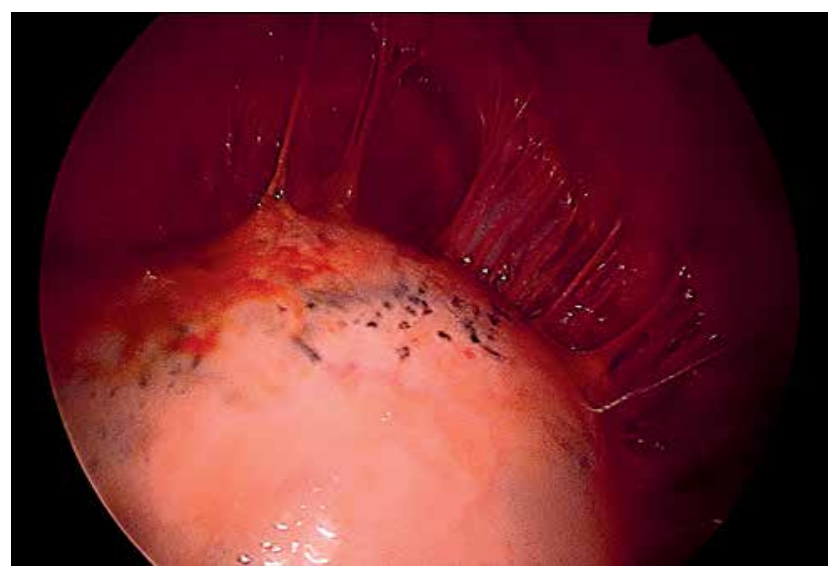

Fig. 1. Pleural adhesions after pleural abrasion visible during the second video-assisted thoracoscopic surgery (VATS) in a 17-yearold patient $p<0.05$. Statistical analysis was performed using SPSS version 18.0.

\section{Discussion}

Patients with primary spontaneous pneumothorax are generally young and healthy. Most cases of primary spontaneous pneumothorax (PSP) occur in healthy adolescents and in young adults in the absence of prior lung disease [5]. The PSP is a relatively rare disease entity in children [5]. According to Margolis et al., who performed a retrospective study of 156 patients with PSP, the median age of presentation was 19 years, and $69 \%$ of patients were male [6]. The goal in the management of PSP is to re-expand the lung and prevent recurrence with minimal morbidity.

Rupture of blebs and bullae may be responsible for the occurrence of most cases of PSP. The formation of bullae is most likely to be multifactorial, including physical characteristics, smoking, anatomic abnormalities of the bronchial tree, sex differences, genetic factors, and growth $[5,7]$. Among our patients there were no smokers, but they generally had asthenic features, and the mean body mass index (BMI) was 20.1. The development of blebs is a dynamic process that often continues throughout adolescence. Previous studies have suggested that growth during adolescence causes a rapid increase in the vertical dimension of the thorax compared to the horizontal dimension. This rapid increase causes an increase in negative pressure at the apex of the lung, which may lead to formation of bullae and may cause PSP upon rupturing $[5,7]$.

The most recent guidelines from the American College of Chest Physicians consensus statement (2001) recommend that patients with small pneumothorax should be observed in the Emergency department for 3-6 hours and discharged home if repeat chest radiograph shows no progression of pneumothorax $[8,9]$. The average rate of recurrent pneumothorax after the first episode of PSP with conservative treatment was reported at 30\% [5], and it seems to be higher in children, ranging from 50 to $60 \%$ $[5,10-12]$.

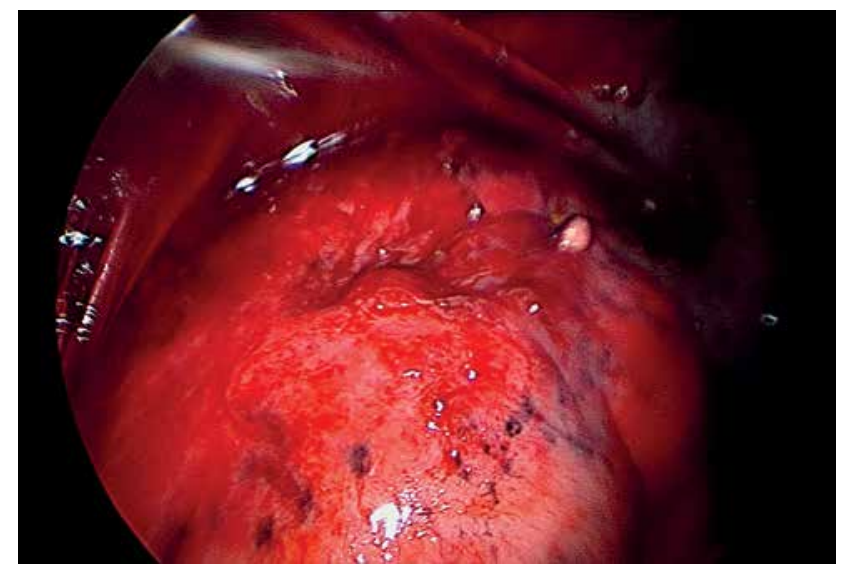

Fig. 2. Apical bleb in a 16-year-old patient 


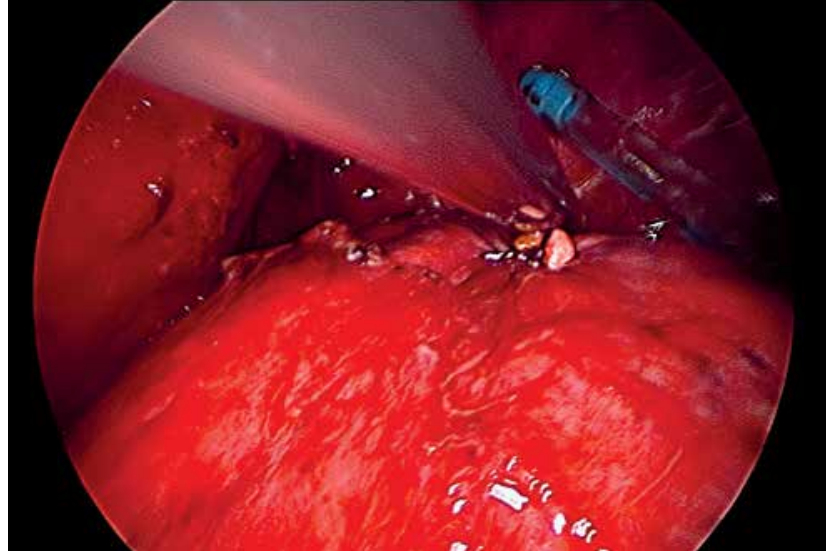

Fig. 3. Resection of apical bleb using an Endoloop in a 16-year-old patient

Traditional preference has been for chest tube insertion and hospitalisation. The British Thoracic Society recommends needle aspiration as the initial treatment of choice [3], but the American College of Chest Physicians Consensus prefers insertion of small-bore catheters $(\leq 14 \mathrm{Fr})$ or chest tubes (16-22 Fr) [9].

Needle aspiration is safe and less painful and leads to a shorter hospital stay than chest tube insertion [13]. However, needle aspiration is only successful in approximately $60 \%$ of patients, and more than half of these patients needed to be hospitalised [14]. Chan and Lam in their study found an even lower success rate after simple needle aspiration of PSP (50.5\%), but only $15 \%$ success rate if the pneumothorax was larger than $40 \%$ [15]. Nonetheless, pain scores were greater in the tube thoracostomy group [2]. In our department we initially treat patients with PSP with chest tube insertion, and in many cases only continuous suction allows complete evacuation of air from the pleural space and full expansion of the lung.

Complications of thoracostomy include subcutaneous emphysema, vasovagal reaction, pneumonia, and haemothorax. Some authors suggest that life-threatening haemothorax might be related to the use of the anterior approach [16]. There are reports of pulmonary artery injury and cardiac tamponade after decompression of the pneumothorax performed in the second intercostal space, midclavicular line $[8,16]$. Bearing in mind those complications we use the fifth intercostal space in the anterior or mid-axillary line for chest tube drainage, and we have not observed thoracostomy complications in our series of patients.

Pulmonary fibrosis, a history of smoking, asthenic habitus, and younger age have been reported to be independent risk factors for recurrences after the first episode of PSP $[5,17]$. Recurrence rates after a first episode of PSP treated with chest drainage vary from 16 to $52 \%$. After a first recurrence, the likelihood of subsequent recurrences seems to increase progressively up to $62 \%$ for a second and $83 \%$ for a third recurrence, which is why an operative intervention is indicated in such cases [1, 18]. Some authors [19] advocate surgery also for patients with air-leak persisting

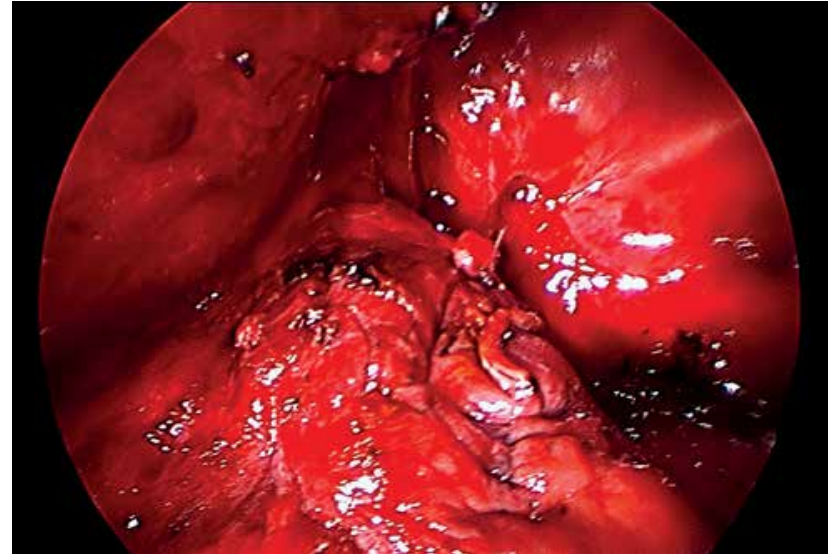

Fig. 4. Line of endo-GIA stapler resection of an apex of left lung because of apical blebs in a 17-year-old patient

beyond 14 days. In our department, patients with PSP are qualified for surgical treatment when air-leak persists beyond seven days. Prior to that, we perform CT of the chest to identify blebs - these patients will benefit from surgical intervention and resection of bullae. Also, the American College of Chest Physicians (ACCP) state that patients should be operated on at the second recurrence, except for those at risk - SCUBA divers, pilots etc., or those presenting with persistent air leak [9].

In the recent years VATS has largely replaced open thoracotomy. Video-assisted thoracoscopic surgery was first reported in 1989 for treatment of secondary spontaneous pneumothorax in children with cystic fibrosis [20]. Later, Rodgers performed VATS for PSP [21]. Video-assisted thoracoscopic surgery is safe and effective, with low morbidity and minimal invasiveness, and has been performed with good results in children with PSP $[5,7,11]$. The recurrence rate of PSP in the group of children after VATS has been reported as $4.9-11.8 \%[5,7,11]$. These recurrence rates are higher than those of adults $1.7-8.3 \%$ [22, 23]. The higher risk of recurrence in children is not related to surgical failure, but it is often associated with the formation of new bullae. It has been reported that in children who develop recurrent PSP, half will have recurrence on the contralateral side [24]. The use of CT scanning is advocated to identify contralateral blebs or bullae [20,24].

The rate of recurrence of first VATS in our study was $50 \%$. We also observed a significant decrease in recurrences with increasing experience, which is consistent with the observations of other authors [25]. The thoracoscopic approach is a relatively new technique, and there is an impact of the learning curve.

The aetiology of postoperative recurrence includes undiscovered bullae, inadequate resection margins that fail to include healthy lung tissue, coexisting severe emphysema, and newly grown bullae $[5,26]$. Several authors have recently reported their experiences with fibrin glue reinforcement of staple lines during thoracoscopic treatment of pulmonary bleb disease in adults $[27,28]$. Comparing the results of chest tube drainage and VATS for recurrent PSP, patients undergoing VATS or limited thoracotomy for PSP 
have recurrence rates of $13 \%$ and $0 \%$, respectively, compared to $42 \%$ after chest tube drainage [29].

After surgical intervention with the resection of blebs with the lung tissue, we advocate our patients to avoid activities that put additional strain on the lungs, including scuba diving, strenuous exercise, and playing wind musical instruments.

A strong and adequate pleural adhesion is indicated to prevent recurrence of the pneumothorax.

Regarding the optimal method for pleurodesis, no consensus has been reached. Reports in adult patients have advocated blebectomy plus mechanical pleurodesis or chemical pleurodesis [22, 23].

Pleurectomy has a very low incidence of recurrence, ranging from 0 to $1 \%$, by open thoracotomy, transaxillary minithoracotomy, or VATS [30]. Unfortunately, pleurectomy may lead to increased morbidity, related to postoperative haemorrhage complications [30, 31]. Also, pleurectomy may make secondary thoracotomy extremely difficult, and performance of an apical pleurectomy alone will not prevent recurrence in the lower part of the chest. Talc poudrage is rarely performed, even though available data show that both VATS bullectomy plus pleurodesis and medical talc poudrage without bullae treatment are equally effective [1]. Talc poudrage has two main drawbacks: the risk of postoperative pleural infection; and the creation of tight adhesions that are difficult to free, so another surgical intervention becomes necessary in the future. In view of those facts, pleural abrasion is widely accepted as a reasonable compromise and is successfully performed in our department.

The 'last resort' treatment for children who have failed VATS is an open thoracotomy with direct surgical treatment of the subpleural bleb or cyst [24]. Several studies comparing VATS to open surgery have documented lower recurrence rates after thoracotomy than after VATS [32-34]. Open thoracotomy is more effective in preventing recurrence but greatly increases discomfort and morbidity. In view of diminishing morbidity, better cosmetic result, and shortening of the hospital stay, in our department we prefer an axillary mini-thoracotomy approach, even though the view offered by an axillary mini-thoracotomy is so limited that it makes it almost impossible to examine the lower lobe [30]. In our series we had to perform thoracotomy only in one patient.

\section{Conclusions}

Although our study is limited by the small number of patients, we conclude that most patients resolve their spontaneous pneumothorax and air leak with tube thoracostomy alone. For those patients in whom chest tube drainage is not effective, and for those with recurrent PSP, early VATS and bullectomy combined with pleural abrasion is the most efficient intervention, obviating long periods of ineffective chest tube drainage.

\section{Disclosure}

Authors report no conflict of interest.

\section{References}

1. Baumann MH, Noppen M. Pneumothorax. Respirology 2004; 9: 157-164.

2. Zehtabchi S, Claritza LR. Management of emergency department patients with primary spontaneous pneumothorax: needle aspiration or tube thoracostomy? Ann Emerg Med 2008; 51: 91-100.

3. Henry M, Arnold T, Harvey J. BTS guidelines for the management of spontaneous pneumothorax. Thorax 2003; 58: 39-52.

4. Dotson K, Timm N, Gittelman M. Is spontaneous pneumothorax really a pediatric problem? A national perspective. Pediatr Emerg Care 2012; 28: 340-344.

5. Choi SY, Kim YH, Jo KH, Kim CK, Park JK, Cho DG, Jeeong SC, Jeon HW, Park CB. Video-assisted thoracoscopic surgery for primary spontaneous pneumothorax in children. Pediatr Surg Int 2013; 29: 505-509.

6. Margolis M, Gharagozloo F, Tempesta B, Trachiotis GD, Katz NM, Alexander EP. Video-assisted thoracic surgical treatment of initial spontaneous pneumothorax in young patients. Ann Thorac Surg 2003; 76: 1661-1663.

7. Lee LP, Lai MH, Chiu WK, Leung MW, Liu KK, Chan HB. Management of primary spontaneous pneumothorax in Chinese children. Hong Kong Med J 2010; 16: 94-100.

8. Chan SSW. The role of simple aspiration in the management of primary spontaneous pneumothorax. J Emerg Med 2008; 34: 131-138.

9. Baumann MH, Strange C, Heffner JE, Light R, Kirby TJ, Klein J, Luketich JD, Panacek EA, Sahn SA; AACP Pneumothorax Consensus Group. Management of spontaneous pneumothorax: an American College of Chest Physicians Delphi Consensus Statement. Chest 2001; 119: 590-602.

10. Butterworth SA, Blair GK, LeBlanc JG, Skarsgard ED. An open and shut case for early VATS treatment of primary spontaneous pneumothorax in children. Can J Surg 2007; 50: 171-174.

11. Qureshi FG, Sandulache VC, Richardson W, Ergun O, Ford HR, Hackam DJ. Primary vs delayed surgery for spontaneous pneumothorax in children: which is better? J Pediatr Surg 2005; 40: 166-169.

12. Seguier-Lipszyc E, Elizur A, Klin B, Vaiman M, Lotan G. Management of primary spontaneous pneumothorax in children. Clin Pediatr (Phila) 2011; 50: 797-802.

13. Ho KK, Onh MEH, Koh MS, Wong E, Raghuram J. A randomized controlled trial comparing minichest tube and needle aspiration in outpatient management of primary spontaneous pneumothorax. Am J Emarg Med 2011; 29: 1152-1157.

14. Noppen M, Alexander P, Driesen P, Slabbynck H, Verstraeten A. Manual aspiration versus chest tube drainage in first episodes of primary spontaneous pneumothorax: a multicenter, prospective, randomized, pilot study. Am J Respir Crit Care Med 2002; 165: 1240-1244.

15. Chan SS, Lam PK. Simple aspiration as initial treatment for primary spontaneous pneumothorax: results of 91 consecutive cases. J Emerg Med 2005; 28: $133-138$

16. Rawlins R, Brown KM, Carr CS, Cameron CR. Life threatening haemorrhage after anterior needle aspiration of pneumothoraces. A role for lateral needle aspiration in emergency decompression of spontaneous pneumothorax. Emerg Med J 2003; 20: 383-384.

17. Sahn SA, Heffner JE. Spontaneous pneumothorax. N Engl J Med 2000; 342: 868-874.

18. MacDuff A, Arnold A, Harvey J; BTS Pleural Disease Guideline Group. Management of spontaneous pneumothorax: British Thoracic Society Pleural Disease Gudeline 2010. Thorax 2010; 65 Suppl 2: ii18-31.

19. Chee CB, Abisheganaden J, Yeo JK, Lee P, Huan PY, Poh SC, Wang YT. Persistent air-leak in spontaneous pneumothorax - clinical course and outcome. Respir Med 1998; 92: 757-761.

20. Guimaraes CV, Donnelly LF, Warner BW. CT findings for blebs and bullae in children with spontaneous pneumothorax and comparison with findings in normal age-matched controls. Pediatr Radiol 2007; 37: 879-884.

21. Daniel TM, Tribble CG, Rodgers BM. Thoracoscopy and talc poudrage for pneumothoraces and effusions. Ann Thorac Surg 1990; 50: 186-189.

22. Cardillo G, Carleo F, Giunti R, Carbone L, Mariotta S, Salvadori L, Petrella L, Martelli M. Videothoracoscopic talc poudrage in primary spontaneous pneumothorax: a single-institution experience in 861 cases. J Thorac Cardiovasc Surg 2006; 131: 322-328.

23. Lang-Lazdunski L, Chapuis O, Bonnet PM, Pons F, Jancovici R. Videothoracoscopic bleb excision and pleural abrasion for the treatment of primary spontaneous pneumothorax: long-term results. Ann Thorac Surg 2003; 75 : 960-965. 
24. Bialas RC, Weiner TM, Phillips D. Video-assisted thoracic surgery for primary spontaneous pneumothorax in children: is there an optimal technique? J Pediatr Surg 2008; 43: 2151-2155.

25. Waller D. Video-assisted thoracoscopic surgery for spontaneous pneumothorax: a 7-year learning experience. Ann Coll Surg Engl 1999; 81: $1387-$ 1392.

26. Sakamoto K, Takei H, Nishii T, Maehara T, Omori T, Tajiri M, Imada T, Takanashi Y. Staple line coverage with absorbable mesh after thoracoscopic bullectomy for spontaneous pneumothorax. Surg Endosc 2004; 18: 478-481.

27. Muramatsu T, Ohmori K, Shimamura M, Furuichi M, Takeshita S, Negishi N. Staple line reinforcement with fleece-coated fibrin glue (TachoComb) after thoracoscopic bullectomy for the treatment of spontaneous pneumothorax. Surg Today 2007; 37: 745-749.

28. Cho S, Huh DM, Kim BH, Lee S, Kwon OC, Ahn WS, Jheon S. Staple line covering procedures after thoracoscopic bullectomy for the management of primary spontaneous pneumothorax. Thorac Cardiovasc Surg 2008; 56: 217-220.
29. Hirai S, Hamanaka Y, Mitsui N, Mrorifuji K, Uegami S, Matsuura Y. Therapeutic strategy for spontaneous pneumothorax. Kyobu Geka 2007; 60: 175-179.

30. Chang YC, Chen CW, Huang SH, Chen JS. Modified needlescopic video-assisted thoracic surgery for primary spontaneous pneumothorax. The longterm effects of apical pleurectomy versus pleural abrasion. Surg Endosc 2006; 20: 757-762.

31. Gossot D, Galetta D, Stern JB, Debrosse D, Caliandro R, Girard P, Grunen wald $D$. Results of thoracoscopic pleural abrasion for primary spontaneous pneumothorax. Surg Endosc 2004; 18: 466-471.

32. Hayland M, Ashrafi A, Crepeau A, Mehran R. Is videoassisted thoracoscopic surgery superior to limited axillary thoracotomy in the management of spontaneous pneumothorax? Can Respir 2001; 8: 339-343.

33. Horio H, Nomori H, Fuyuno G, Kobayashi R, Suemasu K. Limited axillary thoracotomy vs video-assisted thoracoscopic surgery for spontaneous pneumothorax. Surg Endosc 1998; 12: 1155-1158.

34. Kim K, Kook H, Han J, Kim J, Won Y, Choi SS. Transaxillary minithoracotomy versus video-assisted thoracic surgery for spontaneous pneumothorax. Ann Thorac Surg 1996; 61: 1510-1512. 